Louisiana State University

LSU Digital Commons

8-15-2009

\title{
Metabolic depression is delayed and mitochondrial impairment averted during prolonged anoxia in the ghost shrimp, Lepidophthalmus louisianensis (Schmitt, 1935)
}

\author{
Jeremy D. Holman \\ Louisiana State University \\ Steven C. Hand \\ Louisiana State University
}

Follow this and additional works at: https://digitalcommons.Isu.edu/biosci_pubs

\section{Recommended Citation}

Holman, J., \& Hand, S. (2009). Metabolic depression is delayed and mitochondrial impairment averted during prolonged anoxia in the ghost shrimp, Lepidophthalmus louisianensis (Schmitt, 1935). Journal of Experimental Marine Biology and Ecology, 376 (2), 85-93. https://doi.org/10.1016/j.jembe.2009.06.008

This Article is brought to you for free and open access by the Department of Biological Sciences at LSU Digital Commons. It has been accepted for inclusion in Faculty Publications by an authorized administrator of LSU Digital Commons. For more information, please contact ir@lsu.edu. 


\title{
Metabolic Depression is Delayed and Mitochondrial Impairment Averted during Prolonged Anoxia in the ghost shrimp, Lepidophthalmus louisianensis (Schmitt, 1935)
}

\author{
Jeremy D. Holman and Steven C. Hand ${ }^{\star}$ \\ Division of Cellular, Developmental and Integrative Biology, Department of Biological Sciences, \\ Louisiana State University, Baton Rouge, LA 70803 USA
}

\begin{abstract}
Lepidophthalmus louisianensis burrows deeply into oxygen-limited estuarine sediments and is subjected to extended anoxia at low tides. Large specimens $(>2 \mathrm{~g})$ have a lethal time for $50 \%$ mortality $\left(\mathrm{LT}_{50}\right)$ of $64 \mathrm{~h}$ under anoxia at $25^{\circ} \mathrm{C}$. Small specimens $(<1 \mathrm{~g})$ have a significantly higher $\mathrm{LT}_{50}$ of $113 \mathrm{~h}$, which is the longest ever reported for a crustacean. Whole body lactate levels rise dramatically under anoxia and exceed $120 \mu$ mol g.f.w. $^{-1}$ by 72 h. ATP, ADP, and AMP do not change during 48 $\mathrm{h}$ of anoxia, but arginine phosphate declines by over $50 \%$. Thus arginine phosphate may help stabilize the ATP pool. Surprisingly, when compared to the aerobic resting rate, ATP production under anoxia is unchanged during the first $12 \mathrm{~h}$, and drops to only about $50 \%$ between 12 and $48 \mathrm{~h}$. Finally, after $48 \mathrm{~h}$ of anoxia, a major metabolic depression to less than $5 \%$ occurs. Downregulation of metabolism is delayed in L. louisianensis compared to many invertebrates that exhibit facultative anaerobiosis. Bioenergetic constraints as a result of eventual metabolic depression led to ionic disturbances like calcium overload and compromised membrane potential of mitochondria. Because these phenomena trigger apoptosis in mammalian species, we evaluated the susceptibility of ghost shrimp mitochondria to opening of the mitochondrial permeability transition pore (MPTP) and associated damage. Energized mitochondria isolated from hepatopancreas possess a pronounced capacity for calcium uptake. Exogenous calcium does not stimulate opening of the MPTP, which potentially could reduce cell death during prolonged anoxia.
\end{abstract}

\section{Keywords}

Metabolic depression; anoxia; lactate; adenylates; cell death; mitochondrial permeability transition pore

\section{Introduction}

The ghost shrimp, Lepidophthalmus louisianensis (formerly Callianassa jamaicense) is a burrowing decapod crustacean of the infraorder Thalassinidea (Manning and Felder, 1991) that is commonly found in estuaries along the northern Gulf of Mexico. Dense populations of $L$.

(C) 2009 Elsevier B.V. All rights reserved.

*Corresponding author. E-mail: shand@LSU.edu; Tel. No. 01-225-578-5144; Fax 01-225-578-2597; Department of Biological Sciences, 202 Life Sciences Bldg., Louisiana State University, Baton Rouge, LA 70803 USA.

Publisher's Disclaimer: This is a PDF file of an unedited manuscript that has been accepted for publication. As a service to our customers we are providing this early version of the manuscript. The manuscript will undergo copyediting, typesetting, and review of the resulting proof before it is published in its final citable form. Please note that during the production process errors may be discovered which could affect the content, and all legal disclaimers that apply to the journal pertain. 
louisianensis are found in low-energy beaches, back-beach ponds, estuarine tidal flats, and tidal streams where they construct permanent and semi-permanent galleries up to several meters deep into the anoxic, sulfide-rich sediment (Willis, 1942; Felder, 1978; Britton and Morton, 1989; Felder and Griffis, 1994; Felder, 2001). When the tide recedes, the burrow water can become severely hypoxic or anoxic within hours, and during peak low tides or storm surges, these hypoxic conditions can last for days (Felder, 1979). The main objective of the present study is to evaluate a suite of physiological mechanisms that underlie the prolonged anoxia tolerance of this species.

Low resting metabolic rates and critical $\mathrm{PO}_{2}$ values (ambient $\mathrm{PO}_{2}$ at which oxygen consumption decreases linearly with ambient oxygen, $\mathrm{P}_{\text {crit }}$ ) have been observed in $L$. louisianensis by Felder (1979) and Neotrypaea californiensis (formerly Callianassa californiensis) by Thompson and Pritchard (1969) and Torres et al. (1977) as well as other thalassinideans (see Stanzel and Finelli, 2004; Atkinson and Taylor, 2005). As ambient $P_{2}$ approaches the respective $\mathrm{P}_{\text {crit }}$ value, crustaceans recruit fermentative pathways to provide additional ATP. Anaerobic glycolysis leading to the accumulation of lactate is probably the only source of ATP provision during anoxia in Crustacea (Albert and Ellington, 1985; Grieshaber et al., 1994). Generally, lactate fermentation is associated with low tolerance (shortterm survival) under anoxia because the substrate, mostly glycogen, is rapidly consumed (Hochachka, 1980; Hagerman, 1998). This limitation may explain the inability of most decapods to withstand severe hypoxia or anoxia for more than a few hours. Unlike its decapod relatives, L. louisianensis and other thalassinid shrimps survive anoxic conditions in the laboratory for several days (Thompson and Pritchard, 1969; Felder, 1979; Zebe, 1982). Though very small amounts of alanine, aspartate, glutamate, succinate, and malate have been reported in N. californiensis, L-lactate is the principal metabolic end product measured in that species and in Upogebia pugettensis (Pritchard and Eddy, 1979; Zebe, 1982). Unpublished observations suggest that lactate accumulates in L. louisianensis under hypoxia (Felder et al., 1995; Bourgeois and Felder, 2001).

Given that L. louisianensis survives anoxia nearly twice as long as $C$. californiensis and $U$. pugettensis (Felder, 1979), even at warmer temperatures, it is possible that anaerobic end products in addition to lactate are accumulated. Freshwater snails, mussels, oysters, and lugworms have anaerobically functioning mitochondria that accumulate succinate and the volatile fatty acids (VFAs) propionate and acetate via the malate dismutase pathway (see Grieshaber et al., 1994; van Hellemond et al., 1995; Tielens et al., 2002). Unlike aerobic mitochondria, which utilize ubiquinone for electron transfer to Complex III, the transfer of electrons to fumarate under anoxia is accomplished with rhodoquinone (van Hellemond et al., 1995; Tielens et al., 2002). Rhodoquinone is essential for anaerobic accumulation of succinate, propionate, acetate, and other VFAs including isovalerate, methylbutyrate, and isobutyrate (Lahoud et al., 1971; Hochachka, 1980; Holst and Zebe, 1986; Kita, 1992; Tielens, 1994). Thus we measured the amount of rhodoquinone present in the mitochondria of L. louisianensis to gain insight into the capacity for production of non-lactate end products.

Based on the strong positive correlation between the anoxia tolerance of species and their capacity for acute metabolic depression (Hand, 1998; Hochachka and Lutz, 2001), we predicted that under anoxia L. louisianensis would reduce metabolic rate severely and quickly (below $10 \%$ of the aerobic value), which would lower the rate of ATP consumption and conserve carbohydrate fuels. To estimate the degree of metabolic depression, we chose to estimate the rate of ATP turnover under anoxia from end product accumulation and arginine phosphate use, and then express the value as a percentage of the resting aerobic rate as calculated from oxygen consumption. 
Such bioenergetic constraints under anoxia inevitably lead to ionic disturbances like calcium overload in cells, and the compromise of mitochondrial membrane potential $(\Delta \Psi)$ will occur with extended time (Hochachka, 1986; Hand and Menze, 2008). When ATP availability drops so low that active ion transport across membranes cannot keep up with passive ion leak, then dissipation of ion gradients can take place (Covi and Hand, 2005; Covi et al., 2005; Covi and Hand, 2007). These phenomena signal initiation of apoptosis in mammals (Kroemer et al., 2007; Hand and Menze, 2008). Because of the remarkable tolerance to anoxia by $L$. louisianasis, we evaluated the susceptibility of mitochondria of this ghost shrimp to opening of the mitochondrial permeability transition pore (MPTP). If mammalian mitochondria are exposed to elevated calcium in the presence of phosphate, especially when accompanied by depletion of adenine nucleotides and reduced $\Delta \Psi$ across the inner membrane (Petronilli et al., 1993a), a large swelling occurs that is associated with uncoupled respiration and cytochrome$c$ release (Haworth and Hunter, 1979; Hunter and Haworth, 1979; Gunter and Pfeiffer, 1990; Halestrap et al., 2000; Kroemer et al., 2007). These phenomena are due to an acute increase in permeability of the inner mitochondrial membrane known as the permeability transition (Hunter et al., 1976; Bernardi, 1996; Bernardi et al., 2006;). Matrix swelling then causes the rupture of the outer mitochondrial membrane and release of numerous pro-apoptotic factors from the intermembrane space (Green and Reed 1998; Zamzami and Kroemer 2001; Green and Kroemer 2004; Saelens et al. 2004; Bernardi et al. 2006). Surprisingly, Menze et al. $2005 \mathrm{~b}$ noted that the MPTP does not open in response to high calcium in mitochondria from another anoxia-tolerant crustacean, Artemia franciscana, so we hypothesized that the pore may be refractory to anoxia-induced activators in ghost shrimp. As proposed recently (Hand and Menze, 2008), a character trait like prolonged tolerance to anoxia may be a consequence, to some degree, of specific features of apoptosis operative across species. For example, a modest elevation in calcium may trigger apoptosis in mammals, whereas severe energy limitation may not initiate cell death in certain non-mammalian species. Functional trade-offs in the predisposition to environmental tolerance may have occurred in parallel with the evolution of diversified pathways for cell death in eukaryotic organisms.

\section{Materials and Methods}

\subsection{Experimental animals}

Specimens of the ghost shrimp Lepidophthalmus louisianensis were collected during low tide from a mudflat near Waveland, MS (30 $\left.15^{\prime} 24.88^{\prime \prime} \mathrm{N}, 89^{\circ} 24^{\prime} 54.46^{\prime \prime} \mathrm{W}\right)$. The shrimp were flushed from their burrows by liquefying the sediment with a gas-powered water pump. This method yielded numerous shrimp, reduced the number of injured animals, and improved overall survivorship, when compared to the common method of extracting the shrimp from their burrows with negative pressure using a manual water pump ('yabby' pump). On occasion, the latter method was used when only small numbers of shrimp were needed.

Upon collection, shrimp were placed in perforated plastic vials to prevent aggressive interactions and transported to the lab in coolers filled with seawater from the collection site (10-20 practical salinity units, PSU). Following a short quarantine and salinity-acclimation process, the animals contained in vials were transferred to an aquarium equipped with biological, chemical, and mechanical filtration, and plumbed with recirculating artificial seawater (ASW). ASW at a concentration of 20 PSU was used as prescribed by Felder $(1978,1979)$. The highest mortality (normally less than 5\% of animals) occurred within 3 days of collection and was attributed to heavy parasitic infections or handling stress. The aquarium was isolated in a dark room with only brief periods of direct lighting.

Animals used in experiments were kept for a minimum of 3 days and no longer than 2 weeks and were not fed during this period. Intermolt males with no missing appendages and devoid of noticeable parasite infections were selected for experiments. Animals that exhibited black 
discoloration near the gills and those that contained roundworms (most commonly near the heart) were not used. Occasionally, non-ovigerous females were combined with males to obtain sufficient quantities of tissue for mitochondrial studies.

\subsection{Quantification of anoxia tolerance}

In preliminary experiments, we observed that small shrimp ( $<1 \mathrm{~g}$ wet wt.) survived substantially longer in anoxic seawater than large ones ( $>2 \mathrm{~g}$ wet wt.), an observation that prompted us to measure anoxia survival for two size groups. The length of the carapace (CL) from the tip of the rostrum to the posterior margin of the cardiac region was not measured for each animal (but we estimate that even the smallest animals used had a CL >10 mm). Thus all shrimp used were either sexually mature adults or within one molt from sexual maturity according to reproductive studies for this species (Felder and Lovett, 1989).

Large and small adult shrimp, contained in perforated, plastic vials, were placed inside biological oxygen demand (BOD) bottles. Animals were less active and expended less energy in locomotion when inside vials, perhaps because the vials simulated to a degree the confined microenvironment of burrows. Without vials, the shrimp swam continuously in circles and died much earlier under anoxia. The 300-ml BOD bottles were filled with anoxic artificial seawater (20 PSU), sealed with a glass stopper, and placed in a temperature-controlled ( $25^{\circ}$ C) dark room. The seawater was made nominally anoxic by purging with $\mathrm{N}_{2}$ for $1.5 \mathrm{~h}$. Mortality was scored as the inability to stimulate animal movement (e.g., pleopod beating) by rotating the BOD bottle. In early studies, heart rate was also observed, but this second indicator did not enhance the reliability of mortality assessment. Once projected as dead, the shrimp was removed from its bottle and placed in oxygenated water to confirm the absence of recovery (about $98 \%$ of initial projections were accurate). Survivorship was checked every 5-8 h for the first $36 \mathrm{~h}$ of anoxia exposure, and $1-4 \mathrm{~h}$ thereafter. From these data, $\mathrm{LT}_{50}$ values (lethal time for 50\% mortality under anoxia) were calculated. Control animals were kept in open BOD bottles or $100-\mathrm{ml}$ culture tubes with periodic aeration of the seawater. In two separate experiments, the antifungal agent amphotericin $\mathrm{B}\left(2.5 \mathrm{mg} \mathrm{l}^{-1}\right)$ or an antibiotic cocktail of $5 \mathrm{mg}$ $\mathrm{l}^{-1}$ chloramphenicol, $50 \mathrm{mg} \mathrm{l}^{-1}$ gentamycin, 100,000 units $\mathrm{l}^{-1}$ penicillin, and 100,000 $\mathrm{\mu g} \mathrm{l}^{-1}$ streptomycin was added to the seawater to test whether anoxia tolerance for adults of $L$. louisianensis could be extended by restricting growth of fungi or bacteria.

\subsection{Preparation of animal extracts}

Ghost shrimp were exposed to anoxia as above for $6,12,24,48$, and $72 \mathrm{~h}$. At each time point, individuals were removed from their BOD bottles, blotted dry, freeze-clamped in liquid $\mathrm{N}_{2}$, and ground into a fine powder with a pre-chilled mortar and pestle under liquid $\mathrm{N}_{2}$. The frozen powder $(\sim 2 \mathrm{~g})$ was then homogenized in a ground-glass homogenizer containing 5 volumes of ice-cold 6\% perchloric acid (PCA) with $10 \mathrm{mmol} \mathrm{l}^{-1}$ sodium ethylenediaminetetraacetic acid (EDTA). The acid-insoluble fraction was removed by centrifugation for $20 \mathrm{~min}$ at $10,000 \mathrm{~g}$ and $4^{\circ} \mathrm{C}$. The supernatant was then neutralized with ice-cold $5 \mathrm{~mol} \mathrm{l}^{-1} \mathrm{~K}_{2} \mathrm{CO}_{3}$ and centrifuged at $10,000 \mathrm{~g}$ for $10 \mathrm{~min}$ and $4^{\circ} \mathrm{C}$ to remove the potassium perchlorate precipitate. For arginine phosphate, identical procedures were used, but animals were limited to $48 \mathrm{~h}$ of anoxia, and one group was given a $24 \mathrm{~h}$ period of normoxic recovery. For adenylates, each PCA supernatant was divided into two equal aliquots. One aliquot was neutralized with ice-cold $5 \mathrm{~mol} \mathrm{l}^{-1}$ $\mathrm{K}_{2} \mathrm{CO}_{3}$ and the other with ice-cold $5 \mathrm{~mol}^{-1} \mathrm{~K}_{2} \mathrm{HPO}_{4}$, and then both were centrifuged as above to remove perchlorate salts. PCA extracts of tissues associated with molluscan and crustacean exoskeletons contain high $\mathrm{Ca}^{++}$, which can cause significant precipitation of $\mathrm{Ca}^{++}$-ATP and $\mathrm{Ca}^{++}$-ADP upon neutralization of extracts with $\mathrm{K}_{2} \mathrm{CO}_{3}$ (cf. Rees and Hand, 1991), even with EDTA added to the PCA. Unpublished observations suggest that neutralization with $\mathrm{K}_{2} \mathrm{HPO}_{4}$ avoids this problem by preferentially precipitating the $\mathrm{Ca}^{++}$as $\mathrm{CaPO}_{4}$ and leaving the adenylates in solution (C. Ortmann, pers. comm.; Heinrich-Heine University, Duesseldorf, 
Germany). Consequently, we compared the two neutralization procedures. All samples were stored at $-80^{\circ} \mathrm{C}$ until chemical analyses were performed. Upon thawing, any additional precipitate was removed by centrifugation.

\subsection{Enzyme assays for lactate and arginine phosphate}

L-lactate in PCA extracts was measured using a diagnostic kit (Trinity Biotech, Procedure No. 735 , Wicklow, Ireland). With this method, the oxidation of lactate to pyruvate and $\mathrm{H}_{2} \mathrm{O}_{2}$ is catalyzed by lactate oxidase. Using the $\mathrm{H}_{2} \mathrm{O}_{2}$ produced, peroxidase catalyzes the oxidative condensation of chromogen precursors producing a colored dye with an absorption maximum at $540 \mathrm{~nm}$ that is directly proportional to the concentration of lactate in the sample (Jackson et al., 2001). The absorbance change was recorded in 96-well plates using a Spectramax 384 plate reader (Molecular Devices, Sunnyvale, CA). Lactate samples measured with the traditional Bergmeyer protocol based on lactate dehydrogenase (Gutmann and Wahlefeld, 1974) gave identical results, but the Trinity Biotech procedure yielded much higher sample throughput.

Arginine phosphate was quantified using a two-step, enzyme-catalyzed reaction, and the absorbance recorded with a dual beam spectrophotometer (Cary 100 Bio, Varian, Walnut Creek, CA). The protocol was essentially the same as that described by Ellington (1989). The assay medium contained $50 \mathrm{mmol}^{-1}$ imidazole/ $\mathrm{HCl}(\mathrm{pH} 7.0), 2 \mathrm{mM} \mathrm{Mg}$ acetate, $10 \mathrm{mmol}$ $\mathrm{l}^{-1}$ D-glucose, $0.5 \mathrm{mmol} \mathrm{l}^{-1} \mathrm{ADP}, 1 \mathrm{mmol} \mathrm{l}^{-1} \mathrm{NADP}$, and $290 \mu 1$ neutralized supernatant (diluted with deionized $\mathrm{H}_{2} \mathrm{O}$ as needed). After baseline absorbance was recorded at $340 \mathrm{~nm}, 5$ $\mu \mathrm{l}$ of hexokinase/glucose-6-phosphate dehydrogenase enzyme mixture (1.7 units HK, 0.85 units G6PDH; Roche Diagnostics, Mannheim, Germany) was added and the absorbance change recorded. Once all endogenous ATP was consumed, $5 \mu \mathrm{l}$ of arginine kinase (AK; 10-20 mg protein $\mathrm{ml}^{-1}$ stock) was added, and the arginine phosphate concentration was determined from the change in absorbance as calibrated with ATP standards. AK was expressed from a pET 22b plasmid clone (Strong and Ellington 1996), the functional properties of this crustacean enzyme having been described previously (Pruett et al., 2003).

\subsection{HPLC analyses of adenylates}

Analyses were performed using a protocol modified from Menze et al. (2005a) with a Dionex HPLC system (Dionex, Sunnyvale, CA), which consisted of a PDA-100 photodiode array detector, GP-50 gradient pump, AS50 auto sampler, and AS50 thermal compartment. Samples were maintained at $4^{\circ} \mathrm{C}$ in the auto sampler, and $75 \mu \mathrm{l}$ of each sample were applied to a 250 $\times 4.6 \mathrm{~mm}$ strong anion exchange column (Sphereclone $5 \mu \mathrm{SAX} 80 \mathrm{~A}$, Phenomenex, Torrance, CA). The samples were eluted with a linear gradient from $40 \mathrm{mmol} \mathrm{l}^{-1} \mathrm{~K}_{2} \mathrm{HPO}_{4}$ ( $\mathrm{pH}$ 5.5) to $500 \mathrm{mmol} \mathrm{l}^{-1} \mathrm{~K}_{2} \mathrm{HPO}_{4}\left(\mathrm{pH} 5.5\right.$ ) over $26 \mathrm{~min}$ at a flow rate of $1 \mathrm{ml} \mathrm{min}^{-1}$ at $30^{\circ} \mathrm{C}$. The absorbance of the eluent was monitored with a photodiode array detector at wavelengths from 190 to $390 \mathrm{~nm}$. Peaks were identified by analysis of the given peak spectrum from a recorded three-dimensional field with Chromeleon software (Dionex) and by comparison with retention times of standards. Concentrations of AMP, ADP, and ATP were determined from peak area at $260 \mathrm{~nm}$ using Chromeleon software. Calibration curves were linear from $1 \mu \mathrm{mol}^{-1}$ to 1 mmol $1^{-1}$.

\subsection{Isolation of mitochondria}

Mitochondria were isolated from hepatopancreas tissue of shrimp using a protocol similar to Menze et al. (2005b). Hepatopancreas tissue was dissected from 25-30 shrimp (ca. $5 \mathrm{~g}$ of tissue) and pooled in $40 \mathrm{ml}$ of ice-cold isolation buffer $1\left[0.3 \mathrm{~mol}^{-1}\right.$ sucrose, $150 \mathrm{mmol} \mathrm{l}^{-1}$ $\mathrm{KCl}, 1 \mathrm{mmol} \mathrm{l}^{-1}$ EGTA, $0.5 \%$ (wt/vol) fatty acid-free BSA, and $20 \mathrm{mmol}^{-1} \mathrm{~K}^{+}$-HEPES, $\mathrm{pH}$ 7.5]. The isosmotic pressure $(750 \mathrm{mOsm})$ of isolation media for mitochondria of $L$. louisianensis was based on the osmotic and ionic properties of the hemolymph of these shrimp (Felder 1978). The tissue was homogenized in a glass-Teflon homogenizer (Thomas Scientific, 
Swedesboro, NJ) at 1,000-1,100 rpm for six passages. The homogenate was centrifuged for $10 \mathrm{~min}$ at $1,000 \mathrm{~g}$ and $4^{\circ} \mathrm{C}$ to pellet the cellular debris. The supernatant was removed and centrifuged at 9,000 $\mathrm{g}$ for $15 \mathrm{~min}$ to pellet the mitochondria fraction. The resulting pellet was then resuspended in ice-cold isolation buffer $2\left[0.3 \mathrm{~mol} \mathrm{l}^{-1}\right.$ sucrose, $150 \mathrm{mmol} \mathrm{l}^{-1} \mathrm{KCl}, 0.025$ $\mathrm{mmol} \mathrm{l}^{-1}$ EGTA, $0.5 \%$ (wt/vol) fatty acid-free BSA, and $20 \mathrm{mmol}^{-1} \mathrm{~K}^{+}$-HEPES, $\left.\mathrm{pH} 7.5\right]$ and centrifuged again at 9,000 $\mathrm{g}$ and $4^{\circ} \mathrm{C}$. This wash and centrifugation step was repeated, and the final pellet was resuspended in $\sim 1 \mathrm{ml}$ of isolation buffer 2 , which gave a protein concentration of approximately $12-15 \mathrm{mg}$ protein $\mathrm{ml}^{-1}$. Protein was quantified using Coomassie Plus ${ }^{\mathrm{TM}}$ protein assay kit (Pierce, Rockford, IL) with BSA as the standard.

\subsection{Mitochondrial volume change}

Changes in volume of isolated mitochondria were measured spectrophotometrically as described in Menze et al. (2005b) and previously developed by (Petronilli et al., 1993b). A decrease in absorbance at $540 \mathrm{~nm}$ was indicative of an increase in mitochondrial volume (swelling). Measurements of mitochondria $(0.8 \mathrm{mg}$ protein $/ \mathrm{ml})$ were carried out at $25^{\circ} \mathrm{C}$, and the reaction medium contained $300 \mathrm{mmol} \mathrm{l}^{-1}$ sucrose, $150 \mathrm{mmol} \mathrm{l}^{-1} \mathrm{KCl}, 1 \mathrm{mmol}^{-1}$ $\mathrm{KH}_{2} \mathrm{PO}_{4}, 5 \mu \mathrm{mol}^{-1}$ rotenone, $25 \mu \mathrm{mol}^{-1}$ EGTA and $20 \mathrm{mmol}^{-1} \mathrm{~K}$-HEPES, $\mathrm{pH}$ 7.5. Swelling was induced by addition of $\mathrm{HgCl}_{2}$. Calcium does not induce a detectable change in permeability of these mitochondria (see Results). Studies with energized mitochondria were performed in the presence of $5 \mathrm{mmol}^{-1}$ succinate.

\subsection{Fluorescence-based measurements of calcium}

Calcium-induced fluorescence was measured according to Menze et al. (2005b). Assays for calcium uptake by mitochondria were carried out in 96 -well plates in a fluorescence plate reader (Victor 3, PerkinElmer Inc., Wellesley, MA) at $25^{\circ} \mathrm{C}$ in the reaction medium described for the swelling assay above. Studies with energized mitochondria were performed in the presence of $5 \mathrm{mmol} \mathrm{l}^{-1}$ succinate. Mitochondria were de-energized in the absence of succinate by the addition of the uncoupler FCCP (carbonyl cyanide $p$-trifluoromethoxyphenylhydrazone), which serves to abolish the membrane potential. As a control, calcium fluorescence was also measured for isolation buffer 2 without mitochondria. The calcium-sensitive fluorescence probe, fluo-5N, was added at a final concentration of $1 \mu \mathrm{mol} \mathrm{l}^{-1}$ (Blattner et al., 2001), and fluorescence was excited from above the wells $20 \mathrm{~min}$ after addition of calcium. The green fluorescence of fluo- $5 \mathrm{~N}$ was measured using an excitation filter of $485 \mathrm{~nm}$ and an emission filter of $535 \mathrm{~nm}$. Fluorescence was expressed as percent of the maximal fluorescence (\% $\mathrm{F}_{\max }$ ) obtained when the calcium probe was completely saturated with calcium in the respective buffer system. To obtain $F_{\max }$ the fluorescence was measured at intervals across a range of 1 to $1000 \mu \mathrm{mol} \mathrm{l}^{-1}$ calcium. Data were fitted to the function: $\mathrm{F}=\left(\mathrm{K} \cdot \mathrm{X} \cdot \mathrm{F}_{\max }\right) /(1+\mathrm{K} \cdot \mathrm{X})$ using the computer software SigmaPlot Version 9.01 (SPSS Inc., Chicago, IL). In this function, F is the measured fluorescence, $\mathrm{K}$ is the stoichiometric binding constant $\left(1 / \mathrm{K}_{\mathrm{d}}\right)$ of calcium to fluo-5N, $\mathrm{X}$ is the calcium concentration, and $\mathrm{F}_{\max }$ is the maximal obtainable fluorescence.

\subsection{Measurement of rhodoquinone:ubiquinone ratio}

Isolated mitochondria were prepared as described above, except that the final wash and 9000 $g$ centrifugation was omitted and only isolation buffer 1 was used. The final mitochondria pellet was resuspended in $0.5 \mathrm{ml}$ of isolation buffer 1 . The sample was frozen in liquid $\mathrm{N} 2$, lyophilized, and sealed under N2 gas. The sample was shipped to Professor Louis Tielens (Utrecht University, Utrecht, The Netherlands) for analysis of rhodoquinone and ubiquinone by HPLC and mass spectrometry (van Hellemond et al., 1995; Hoffmeister et al., 2004). 


\subsection{Statistical analyses}

GraphPad Prism Version 5.0 (GraphPad Software, San Diego, CA) was used for analysis of anoxia survival. The non-parametric Kaplan-Meier method was used to calculate median survival times ( $\mathrm{LT}_{50}$ values). A log-rank test (Mantel-Cox) was then used for comparing the two survival curves. SigmaStat 3.0 software (SPSS Inc., Chicago, IL) was used to perform all other statistical analyses. For lactate and arginine phosphate data, all tests for normality (Kolmogorov-Smirnov test) failed. Therefore, a Kruskal-Wallis ANOVA on ranks test was used. When differences within a treatment group were detected, the Tukey method was used for multiple comparisons between individual time points. For calcium-based fluorescence assays, simple t-tests were used.

\section{Results}

\subsection{Anoxia tolerance}

Survival under anoxia was evaluated independently for two size classes of $L$. louisianensis. Both size classes exhibited remarkable capacities for anoxia tolerance, with all animals surviving at least $24 \mathrm{~h}$ at $25^{\circ} \mathrm{C}$. The LT50 for large shrimp ( $>2 \mathrm{~g}$ ) was $64.8 \mathrm{~h}$ (Figure 1) with one shrimp surviving $92 \mathrm{~h}$ without oxygen. In contrast, the $\mathrm{LT}_{50}$ for small shrimp $(<1 \mathrm{~g})$ was $113 \mathrm{~h}$, which was nearly twice that of the large shrimp (Figure 1). The difference between survival curves for the two size groups was significant $(\mathrm{P}<0.0001)$. Control animals for both size classes suffered little mortality during these trials, with less than $15 \%$ dying within 10 days and most living beyond 3 to 4 weeks (data not shown). Addition of either an antibiotic cocktail (Materials and Methods) or a fungicide (amphotericin B) did not extend the survival of adults or juveniles ( $\mathrm{LT}_{50}$ of 62 and $100.5 \mathrm{~h}$, respectively, using the antibiotic cocktail).

\subsection{Metabolite levels during anoxia}

Lactate accumulation in whole-animal extracts of L. louisianensis (large shrimp only) was negligible in the control group (Figure 2), but rose 18-fold in animals exposed to anoxia for 6 $\mathrm{h}$. After $12 \mathrm{~h}$ of anoxia, lactate reached levels more than 40 -fold those of control animals and more than 60 -fold those of the controls after $24 \mathrm{~h}$. Lactate concentration appeared to reach a plateau after $48 \mathrm{~h}\left(118 \pm 17.0 \mu\right.$ moles g.f.w. ${ }^{-1}$, mean $\left.\pm \mathrm{SD}, \mathrm{N}=6\right)$ with no significant increase observed at $72 \mathrm{~h}$ of anoxia $(\mathrm{P}>0.05$, versus $48 \mathrm{~h})$.

It is noteworthy that statistically-significant differences in AMP, ADP, or ATP were not detected over the duration of the anoxia exposures (Table 1). Neither were there statisticallysignificant changes in the total pool of adenylates, ATP:ADP ratio, AMP:ATP ratio, or the AEC (Figure 3).

The method by which perchloric acid extracts were neutralized had a profound effect on adenylate levels measured in the samples. An example is shown in Figure 4, where very little ATP was detectable in an extract neutralized with $5 \mathrm{M} \mathrm{K}_{2} \mathrm{CO}_{3}$, yet the same extract (equal volume derived from the same animal) neutralized with $\mathrm{K}_{2} \mathrm{HPO}_{4}$ contained substantially more ATP. This large difference was not observed for all extracts, but was sufficiently frequent that the adenylate data set collected with $\mathrm{K}_{2} \mathrm{CO}_{3}$ neutralization was discarded. The most likely reason for the large adenylate variability seen with $\mathrm{K}_{2} \mathrm{CO}_{3}$ is high and variable contents of calcium among samples, which caused precipitation of ATP and ADP during neutralization unless prevented by the presence of phosphate ion. Calcium binds tightly to phosphate and forms calcium phosphate precipitates.

The pool of arginine phosphate in L. louisianensis declined slowly across the anoxia time course (Figure 3). Arginine phosphate was significantly lower than the control value after 12, 24 and $48 \mathrm{~h}$ of anoxia. Arginine phosphate declined to a low of $3.78 \pm 0.93 \mu$ moles g.f.w. $^{-1}$ 
by $48 \mathrm{~h}$, which represents more than a $50 \%$ reduction from control levels $(8.22 \pm 0.45 \mu$ moles g.f.w. ${ }^{-1}$ ). The pool of arginine phosphate returned to control levels by $24 \mathrm{~h}$ post-anoxia.

Potential end-products of anaerobic metabolism other than lactate were not investigated primarily due to the finding that mitochondria of L. louisianensis do not contain physiologically-significant levels of rhodoquinone. The insignificant amount of rhodoquinone detected was less than $0.1 \%$ of the ubiquinone pool. The presence of rhodoquinone is a prerequisite for mitochondrial-based pathways utilized in some species under anoxia to expand the ATP yield and increase the diversity of end products produced. In such cases, rhodoquinone levels are at least $10 \%$ of the ubiquinone pool (Tielens et al., 2002).

\subsection{Mitochondrial swelling and $\mathrm{Ca}^{2+}$ uptake}

Swelling due to the opening of the MPTP can be observed as a decrease in the absorbance of mitochondria at $540 \mathrm{~nm}$ (Petronilli et al., 1993b). As shown in Figure 5, absorbance actually increases when $1 \mathrm{mmol}^{-1}$ calcium is added exogenously to energized mitochondria isolated from hepatopancreas tissue in L. louisianensis. The absence of a decrease in absorbance suggests that mitochondria from $L$. louisianensis do not experience an MPTP opening under physiological conditions that would trigger MPTP opening in mammals (cf. Menze et al., 2005b). The increase in absorbance observed is indicative of the transport of large quantities of calcium into the matrix (see Discussion). Addition of $20 \mu \mathrm{moll}^{-1} \mathrm{HgCl}_{2}$, a non-physiological inducer of mitochondrial swelling, causes a profound decrease in absorbance of these mitochondria as expected (Figure 5). The mercury tracing serves as a positive control, which indicates that if swelling had been induced by calcium-dependent opening of the MPTP, the assay was adequate for detection.

A high capacity for calcium uptake was observed for energized mitochondria ( $\sim .8 \mathrm{mg}$ protein $\mathrm{ml}^{-1}$ ) isolated from this anoxia-tolerant invertebrate. Because the fluo- $5 \mathrm{~N}$ dye cannot penetrate the mitochondrion, the fluorescence values measured are correlated with the external free calcium concentration for values below the saturation signal of the calcium probe. In the absence of exogenously-added calcium, fluorescence was detected in solutions containing deenergized and energized mitochondria, as well as in the control without mitochondria, which indicates some calcium contamination is present on the glassware and in the mitochondrial preparations. At each concentration of exogenously added calcium, the fluorescence for deenergized preparations of mitochondria is statistically the same as the control. However, energized mitochondria significantly reduce the level of exogenously added calcium below the control at each concentration investigated. Above $0.2 \mathrm{mmol}^{-1}$ exogenous calcium, the free calcium levels begin to rise in energized mitochondrial preparations, but even at $1 \mathrm{mmol}^{-1}$ calcium, fluorescence remains significantly lower than that of the control (Figure 6). Thus, the capacity for calcium uptake by ghost shrimp mitochondria is very high. Even more noteworthy, there is a lack of calcium-induced release of calcium from the mitochondrial matrix in both energized and de-energized mitochondria.

\section{Discussion}

We have shown in this study that $L$. louisianensis has a remarkable tolerance to anoxia, and that it accumulates extremely high concentrations of lactate when exposed to chronic anoxia. To our knowledge, the lactate concentrations observed after $72 \mathrm{~h}$ of anoxia (over $125 \mu \mathrm{mol}$ g.f.w. ${ }^{-1}$ ) are the highest ever reported for a crustacean species (cf. Zebe, 1982; Albert and Ellington, 1985; Taylor and Spicer, 1987; Hill et al., 1991; Anderson et al., 1994; Henry et al., 1994; Adamczewska and Morris, 2001; Burnett et al., 2006). Our data also suggest that this species may utilize, to a minor degree, arginine phosphate to buffer changes in ATP levels under anoxia. However, a far more substantial contribution to the maintenance of energetic status comes from the high rate of anaerobic glycolysis. Using simple calculations based on 
changes in lactate and arginine phosphate in this study and measurements of the resting metabolic rate $\left(\mathrm{MO}_{2}\right)$ of similar-sized animals by Felder (1979), we show that $L$. louisianensis maintains its ATP production rate at near-aerobic levels during the initial $12 \mathrm{~h}$ of anoxia, and between 12 and $48 \mathrm{~h}$ of anoxia, still supports about $50 \%$ of its aerobic metabolism. Only after $48 \mathrm{~h}$, does a major depression of metabolism occur, down to less than $5 \%$ (Table 2). Based on these data, it appears that downregulation of metabolism is delayed in L. louisianensis until after high levels of lactate are accumulated. This metabolic approach would support substantial physiological activities through $48 \mathrm{~h}$. Behaviorally, for example, the delayed downregulation could permit periodic irrigation of the burrow as a way to detect the tidal return of high- $\mathrm{PO}_{2}$ water outside the burrow. Locomotory movements to explore different regions of the gallery could be advantageous for similar reasons. Finally, calcium plus phosphate does not trigger opening of the regulated MPTP in mitochondria from $L$. louisianensis as it does in mammalian mitochondria. This result is significant in that it indicates this animal may be predisposed to extended anoxia tolerance. As postulated by Hand and Menze (2008), the evolution of diversified mechanisms for initiating cell death in mammals, for example, may have occurred in parallel with functional trade-offs in environmental tolerance.

\subsection{Survival under anoxia}

The mean survival time $\left(\mathrm{LT}_{50}\right)$ of $L$. louisianensis under anoxia in our study was $64.8 \mathrm{~h}$ for the large size class, which is slightly lower than the 3.2 days ( $\sim 76 \mathrm{~h})$ reported for similarly-sized animals of the same species under identical conditions by Felder (1979). This small difference is likely within the experimental error for the two studies. Interestingly, both of these independent studies reveal a higher $\mathrm{LT}_{50}$ for this species than what is reported for other thalassinideans under anoxia. For example, specimens of Calocaris macandreae survive only $43 \mathrm{~h}$ at $10^{\circ} \mathrm{C}$ (Anderson et al., 1994). Specimens of Neotrypaea californiensis (formerly Callianassa) were originally reported to survive $138 \mathrm{~h}$ without oxygen at $10^{\circ} \mathrm{C}$ (Thompson and Pritchard, 1969), but later were found to survive only 52-60 h at $12^{\circ} \mathrm{C}$ (Zebe, 1982). The warmer habitats of L. louisianensis may experience more frequent and longer episodes of anoxia compared to the colder-water habitats. Whatever the case, no other decapods have been shown to survive such extended periods of anoxia in the laboratory.

The smaller size class of ghost shrimp $(<1 \mathrm{~g})$ used in this study survived anoxia nearly twice as long as the larger shrimp. The basis for this result is unclear at present. One possibility is that the smaller animals possess a greater capacity for metabolic depression than do larger ones, and thus glycogen stores would presumably last longer during anaerobic metabolism. Our biochemical data were restricted to the larger size class for the practical reason of ample quantities of tissue, but it would be interesting in future studies to follow metabolite changes in small animals and to also compare rates of metabolic heat dissipation between large and small specimens under anoxia. An alternative explanation is related to experimental conditions -- both size classes were exposed to anoxia in the same volume $(300 \mathrm{ml})$ of water. One might argue that higher concentrations of waste products (e.g., protons, ammonia) accumulate in containers with the larger animals and reduce their survivorship. When Felder (1979) replaced anoxic water daily, the $\mathrm{LT}_{50}$ for L. louisianensis increased from 3.2 to 4 days.

Treatment of the clam Macoma balthica with chloramphenicol significantly increased the $\mathrm{LT}_{50}$ in anoxia from 4.8 to 13.3 days (de Zwaan et al., 2001). The same treatment extended the $\mathrm{LT}_{50}$ in anoxia of the clam Chamelea gallina from 2.1 to 11.0 days (de Zwaan et al., 2002). Use of chloramphenicol, gentamycin, and penicillin/streptomycin did not significantly change the $\mathrm{LT}_{50}$ for L. louisianensis in anoxia, nor did the addition of amphotericin $\mathrm{B}$. 


\subsection{Lactate Generation}

Whole-animal analysis of lactate during selected periods of anoxia exposure revealed extremely high concentrations of this end product of anaerobic metabolism (Figure 2). Lactate values have not been reported previously for this species under anoxia, although commentary has previously indicated that lactate production occurs in this species (cf. Felder et al., 1995; Borgeois and Felder, 2001). Lactate accumulation has been quantified in a few other thalassinidean shrimp, but many of the early studies on this examined only hemolymph lactate. Lactate accumulated slowly in tissues of Calocaris macandreae and $N$. californiensis; values reached $16.8 \pm 0.28 \mu \mathrm{mol}$ g.f.w. ${ }^{-1}$ by $24 \mathrm{~h}$ in $N$. californiensis (Zebe, 1982) and $11.6 \mu \mathrm{mol}$ g.f.w. ${ }^{-1}$ by $18 \mathrm{~h}$ in C. macandreae (Anderson et al., 1994). Comparatively, L. louisianensis produced nearly 3 -fold more lactate $\left(65.2 \pm 9.6 \mu\right.$ mol g.f.w. $\left.^{-1}\right)$ by $24 \mathrm{~h}$ of anoxia, albeit at a much higher ambient temperature (Figure 2). By $48 \mathrm{~h}$, the concentration in L. louisianensis nearly doubled $\left(118 \pm 17.0 \mu\right.$ mol g.f.w. $\left.{ }^{-1}\right)$. Temperature alone could account for a considerable fraction of the difference in lactate accumulation among these species of thalassinidean shrimp. One would predict that survival under anoxia would increase and the rate of lactate accumulation would decrease in L. louisianensis at lower temperatures.

\subsection{Maintenance of adenylate pools and delayed metabolic depression}

Phosphagen systems such as creatine phosphate and arginine phosphate have been shown to buffer the loss of ATP during functional and environmental anaerobiosis (reviewed in Grieshaber et al., 1994 and Ellington, 2001). This mechanism may be operative to some degree in the maintenance of adenylate levels and the adenylate energy charge (AEC) in $L$. louisianensis (Table 1 and Figure 3). A 21\% reduction in arginine phosphate was observed in the first $6 \mathrm{~h}$ of anoxia, while no significant change was observed in any of the adenylates. By $48 \mathrm{~h}$, the arginine pool was reduced by $54 \%$ in the face of a stable ATP values. However, considering the small absolute drop in arginine phosphate, the quantitative contribution to adenylate stability is minor, when compared to the large ATP yield from lactate (cf. Table 2). Nevertheless, when combined, these two sources of ATP are sufficient to fully stabilize the adenylate pool during the $48 \mathrm{~h}$ bout of anoxia in tissues of $L$. louisianensis. There was a trend in the means for both ATP and the total adenylate pool to decrease slightly with exposure time, but the fairly large SEs precluded any statistical resolution of these patterns.

A novel and surprising insight is revealed from the calculations in Table 2, which suggest that during early stages of anoxia the sources of ATP above are sufficient to support a metabolic rate similar to that observed in normoxic-exposed animals at rest. From $0-6 \mathrm{~h}$, it appears that the shrimp can sustain up to $72 \%$ of the aerobic rate of ATP generation from lactate and arginine phosphate metabolism. Between 6 and $12 \mathrm{~h}$ anoxia, the value increases to $100 \%$. Finally, between 12 and $48 \mathrm{~h}$, there appears to be a substantial metabolic depression under anoxia compared to normoxia (metabolism reduced to $30-50 \%$ of resting aerobic rate). Deep metabolic depression under anoxia finally occurs between 48 and $72 \mathrm{~h}$ of anoxia, when the calculated metabolism is only 3-4\% of the resting normoxic rate. Metabolic depression to 5$10 \%$ under anoxia is commonly observed in tolerant invertebrates, and the degree of depression is strongly correlated with anoxic survivorship (Hand and Hardewig, 1996;Hand, 1998). An animal capable of surviving more than a few hours of anoxia would be expected to reduce metabolism to pilot-light levels for the duration of anoxia exposure (Hochacka and Lutz, 2001). However, such a downregulation is delayed in L. louisianensis.

\subsection{Absence of a regulated MPTP}

Our data demonstrate that $1 \mathrm{mmol}^{-1}$ calcium does not induce swelling in the mitochondria from L. louisianensis and suggests that a regulated MPTP does not exist. Instead, addition of calcium caused an increase in absorbance, i.e., an apparent decrease in mitochondrial volume (Figure 5). Actually, it is unlikely that any shrinkage occurred, but rather that the formation of 
$\mathrm{Ca}^{2+}$-phosphate complexes in the matrix during high calcium uptake caused an increase in the refractive index of the matrix (Andreyev et al., 1998;Chalmers and, 2003;Nicholls and Chalmers, 2004). Addition of high concentrations of mercury $\left(20 \mu \mathrm{mol}^{-1}\right)$ to mitochondria has been shown to induce mitochondrial permeabilization by unspecific "damage" of membrane proteins that leads to opening of an un-regulated pore (He and Lemaster, 2002). Mercury caused substantial swelling of mitochondria of $L$. louisianensis (Figure 5). The observation serves as an important positive control by documenting the capacity of ghost shrimp mitochondria to swell and our ability to detect it. The absence of a MPTP is confirmed by the calcium uptake/release data in Figure 6, which shows that across a wide range of added calcium, release of matrix calcium (diagnostic of MPTP opening) does not occur in mitochondria of $L$. louisianensis. In fact mitochondria of $L$. louisianensis continue to actively load calcium even when challenged with $1 \mathrm{mmol} \mathrm{l}^{-1}$ extra-mitochondrial calcium.

The lack of a calcium-induced permeability transition and the high calcium uptake capacity was also observed in Artemia franciscana by Menze et al. (2005b) and may be a general feature of invertebrates. MPTP opening is a key step in the initiation of apoptosis and cell death in the hypoxia-sensitive mammals and is triggered by high levels of intracellular calcium, in addition to other signals (Ichas and Mazat, 1998; Jiang and Wang, 2004). Briefly, opening of the MPTP in mammalian mitochondria causes swelling, which then ruptures the outer membrane and releases cytochrome $\mathrm{c}$. In mammals, cytochrome $c$ then stimulates caspase-dependent apoptosis by binding to Apaf-1 (Kroemer et al., 2007); the complex then can recruit and activate caspases. Elevated calcium is a hallmark of many cell types exposed to prolonged anoxia (Hochachka, 1986). It could be interpreted that the lack of MPTP opening under conditions of high calcium is a predisposition for extended anoxia tolerance in non-mammalian species.

In summary, the anoxia tolerance of the ghost shrimp L. louisianensis is among the highest, if not the highest, ever reported for a decapod species. Surprisingly, the animal exhibits only modest metabolic depression during the first $12 \mathrm{~h}$. The depression is significantly delayed compared to other invertebrates, but eventually low metabolic rates (3-4\% of normoxic values) are reached after $48 \mathrm{~h}$. Lactate production is very high in tissues and appears to be the primary source of anaerobic ATP generation as in other crustaceans, which is supported in $L$. louisianensis by the very low levels of rhodoquinone. The lack of a regulated MPTP in $L$. louisianensis may be a general feature of invertebrates that contributes to an extended anoxia tolerance.

\section{Acknowledgments}

Thanks are extended to Dr. Michael Menze (Louisiana State University) for useful advice on measurements of mitochondrial calcium uptake and swelling and to Dr. Darryl Felder (University of Louisiana, Lafayette) for insights into the biology and collection of ghost shrimp. Dr. Ross Ellington (Florida State University) generously provided the arginine kinase used in our assays of arginine phosphate. We thank Dr. Louis Tielens (Utrecht University, Utrecht, The Netherlands) for his analysis of rhodoquinone and ubiquinone in ghost shrimp mitochondria. Ms. Evelyn Tan is acknowledged for her assistance with animal collection. Support for this study was provided by NIH grant 1-RO1GM071345-01, and a Grant in Aid of Research from the Sigma Xi Foundation to JH.

\section{References}

Adamczewska AM, Morris S. Metabolic status and respiratory physiology of Gecarcoidea natalis, the Christmas Island red crab, during the annual breeding migration. Biol. Bull 2001;200:321-335. [PubMed: 11441974]

Albert JL, Ellington WR. Patterns of energy metabolism in the stone crab, Menippe mercenaria, during severe hypoxia and subsequent recovery. J. Exp. Zool 1985;234:175-183. [PubMed: 3998676]

Anderson SJ, Taylor AC, Atkinson RJA. Anaerobic metabolism during anoxia in the burrowing shrimp Calocaris macandreae Bell (Crustacea: Thalassinidea). Comp. Biochem. Physiol 1994;108A:515-522. 
Andreyev AY, Fahy B, Fiskum G. Cytochrome c release from brain mitochondria is independent of the mitochondrial permeability transition. FEBS Lett 1998;439:373-376. [PubMed: 9845356]

Atkinson, RJA.; Taylor, AC. Aspects of the physiology, biology and ecology of thalassinidean shrimps in relation to their burrow environment. In: Gibson, RN.; Atkinson, RJA.; Gordon, JDM., editors. Oceanography and marine Biology: An annual review. Vol. Vol 43. London: CRC Press; 2005. p. 173-210.

Bernardi P. The permeability transition pore. Control points of a cyclosporine A-sensitive mitochondrial channel involved in cell death. Biochim. Biophys. Acta 1996;1275:5-9.

Bernardi P, Krauskopf A, Basso E, Petronilli V, Blachly-Dyson E, Di Lisa F, Forte MA. The mitochondrial permeability transition from in vitro artifact to disease target. Febs. J 2006;273:20772099. [PubMed: 16649987]

Bourgeois RP, Felder DL. Postexposure metabolic effects of sulfide and evidence of sulfide-based ATP production in callianassid ghost shrimp (Crustacea : Decapoda : Thalassinidea). J. Exp. Mar. Biol. Ecol 2001;263:105-121.

Blattner JR, He LH, Lemasters JJ. Screening assays for the mitochondrial permeability transition using a fluorescence multiwell plate reader. Anal. Biochem 2001;295:220-226. [PubMed: 11488625]

Britton, JC.; Morton, B. Shore Ecology of the Gulf of Mexico. Austin: University of Texas Press; 1989.

Burnett LE, Holman JD, Jorgensen DD, Ikerd JL, Burnett KG. Immune defense reduces respiratory fitness in Callinectes sapidus, the Atlantic blue crab. Biol. Bull 2006;211(1):50-57. [PubMed: 16946241]

Chalmers S, Nicholls DG. The relationship between free and total calcium concentrations in the matrix of liver and brain mitochondria. J. Biol. Chem 2003;278:19062-19070. [PubMed: 12660243]

Covi JA, Hand SC. V-ATPase expression during development of Artemia franciscana embryos: potential role for proton gradients in anoxia signaling. J. Exp. Biol 2005;208:2783-2798. [PubMed: 16000547]

Covi JA, Hand SC. Energizing an invertebrate embryo: bafilomycin dependent respiration and the metabolic cost of proton pumping by the V-ATPase. Physiol. Biochem. Zool 2007;80:422-432. [PubMed: 17508337]

Covi JA, Treleaven WD, Hand SC. V-ATPase inhibition prevents recovery from anoxia in Artemia franciscana embryos: quiescence signaling through dissipation of proton gradients. J. Exp. Biol 2005;208:2799-2808. [PubMed: 16000548]

de Zwaan A, Babarro JM, Monari M, Cattani O. Anoxic survival potential of bivalves: (arte)facts. Comp. Biochem. Physiol. A Mol. Integr. Physiol 2002;131:615-624. [PubMed: 11867287]

de Zwaan A, Schaub BE, Babarro JM. Anoxic survival of Macoma balthica: the effect of antibiotics, molybdate and sulphide. J. Exp. Mar. Biol. Ecol 2001;256:241-251. [PubMed: 11164866]

Ellington WR. Phosphocreatine represents a thermodynamic and functional improvement over other muscle phosphagens. J. Exp. Biol 1989;143:177-194. [PubMed: 2543728]

Ellington WR. Evolution and physiological roles of phosphagen systems. Annu. Rev. Physiol 2001;63:289-325. [PubMed: 11181958]

Felder DL. Osmotic and ionic regulation in several western Atlantic Callianassidae (Crustacea, Decapoda, Thalassinidea). Biol. Bull 1978;154:409-429.

Felder DL. Respiratory adaptations of the estuarine mud shrimp, Callianassa jamaicense (Schmitt, 1935) (Crustacea, Decapoda, Thalassinidea). Biol. Bull 1979;157:125-137.

Felder DL. Diversity and ecological significance of deep-burrowing macrocrustaceans in coastal tropical waters of the Americas (Decapoda : Thalassinidea). Interciencia 2001;26:440-449.

Felder, DL.; Griffis, RB. Dominant infaunal communities at risk in shoreline habitats: Burrowing thalassinid Crustacea. OCS Study \# MMS 94-0007. New Orleans: U.S. Dept. of the Interior, Minerals Mgmt. Service, Gulf of Mexico OCS Regional Office; 1994.

Felder DL, Lovett DL. Relative growth and sexual maturation in the estuarine ghost shrimp Callianassa louisianensis Schmitt, 1935. J. Crustacean Biol 1989;9:540-553.

Felder, DL.; Nates, SF.; Duhon, D. Invasion and colonization of tropical penaeid shrimp farms by thalassinid mud shrimp: the ecological scenario and biogeochemical consequences. In: Browdy, CL.; Hopkins, JS., editors. Swimming through troubled waters: proceedings of the special session on shrimp farming. San Diego: The World Aquaculture Society; 1995. p. 240-241. 
Green DR, Kroemer G. The pathophysiology of mitochondrial cell death. Science 2004;305:626-629. [PubMed: 15286356]

Green DR, Reed JC. Mitochondria and apoptosis. Science 1998;281:1309-1312. [PubMed: 9721092]

Grieshaber MK, Hardewig I, Kreutzer U, Portner HO. Physiological and metabolic responses to hypoxia in invertebrates. Rev Physiol. Biochem. Pharmacol 1994;125:43-147. [PubMed: 7984874]

Gunter TE, Pfeiffer DR. Mechanisms by which mitochondria transport calcium. Am. J. Physiol 1990;258:C755-C786. [PubMed: 2185657]

Gutmann, I.; Wahlefeld, AW. L-(+)-Lactate determination with lactate dehydrogenase and NAD. In: Bergmeyer, HU., editor. Methods of Enzymatic Analysis. 2nd. Vol. vol. 3. New York: Academic Press; 1974. p. 1465-1472.

Hagerman L. Physiological flexibility; a necessity for life in anoxic and sulphidic habitats. Hydrobiologia 1998;375(376):241-254.

Halestrap AP, Doran E, Gillespie JP, O’Toole A. Mitochondria and cell death. Biochem. Soc. Trans 2000;28:170-177. [PubMed: 10816121]

Hand SC. Quiescence in Artemia franciscana embryos: reversible arrest of metabolism and gene expression at low oxygen levels. J. Exp. Biol 1998;201:1233-1242. [PubMed: 9510534]

Hand SC, Hardewig I. Downregulation of cellular metabolism during environmental stress: mechanisms and implications. Annu. Rev. Physiol 1996;58:539-563. [PubMed: 8815808]

Hand SC, Menze MA. Mitochondria in energy-limited states: Mechanisms that blunt the signaling of cell death. J. Exp. Biol 2008;211:1829-1840. [PubMed: 18515712]

Haworth RA, Hunter DR. The $\mathrm{Ca}^{2+}$-induced membrane transition in mitochondria. II. Nature of the $\mathrm{Ca}^{2+}$ trigger site. Arch. Biochem. Biophys 1979;195:460-467. [PubMed: 38751]

He L, Lemasters JJ. Regulated and unregulated mitochondrial permeability transition pores: a new paradigm of pore structure and function? FEBS Lett 2002;512:1-7. [PubMed: 11852041]

Henry RP, Booth CE, Lallier FH, Walsh PJ. Post-exercise lactate production and metabolism in three species of aquatic and terrestrial decapod crustaceans. J. Exp. Biol 1994;186:215-234. [PubMed: 9317667]

Hill AD, Taylor AC, Strang RHC. Physiological and metabolic responses of the shore crab Carcinus maenus (L.) during environmental anoxia and subsequent recovery. J. Exp. Mar. Biol. Ecol 1991;150 (1):31-50.

Hochachka, PW. Living without oxygen: closed and open systems in hypoxia tolerance. Cambridge, U.S.A: Harvard University Press; 1980.

Hochachka PW. Defense strategies against hypoxia and hypothermia. Science 1986;231:234-241. [PubMed: 2417316]

Hochachka PW, Lutz PL. Mechanism, origin, and evolution of anoxia tolerance in animals. Comp. Biochem. Physiol. Part B: Biochem. Mol. Biol 2001;130:435-459.

Hoffmeister M, van der Klei A, Rotte C, van Grinsven KWA, van Hellemond JJ, Henze K, Tielens AGM, Martin W. Euglana gracilis rhodoquinone:ubiquinone ratio and mitochondrial proteome differ under aerobic and anaerobic conditions. J. Biol. Chem 2004;279(21):22422-22429. [PubMed: 15014069]

Holst H, Zebe E. Volatile fatty acid excretion during anaerobiosis in the lugworm Arenicola marina. Comp. Biochem. Physiol 1986;83A:189-196.

Hunter DR, Haworth RA. The $\mathrm{Ca}^{2+}$-induced membrane transition in mitochondria. I. The protective mechanisms. Arch. Biochem. Biophys 1979;195:453-459.

Hunter DR, Haworth RA, Southard JH. Relationship between configuration, function, and permeability in calcium-treated mitochondria. J. Biol. Chem 1976;251:5069-5077. [PubMed: 134035]

Ichas F, Mazat JP. From calcium signaling to cell death: two conformations for the mitochondrial permeability transition pore. Switching from low- to high-conductance state. Biochim. Biophys. Acta 1998;1366:33-50. [PubMed: 9714722]

Jackson DC, Wang T, Koldkjaer P, Taylor EW. Lactate sequestration in the carapace of the crayfish Austropotamobius pallipes during exposure in air. J. Exp. Biol 2001;204:941-946. [PubMed: 11171417]

Jiang X, Wang X. Cytochrome c-mediated apoptosis. Annu. Rev. Biochem 2004;73:87-106. [PubMed: 15189137] 
Kita K. Electron-transfer complexes of mitochondria in Ascaris suum. Parasitol 1992:155-159. Today 8.

Kroemer G, Galluzzi L, Brenner C. Mitochondrial membrane permeabilization in cell death. Physiol. Rev 2007;87:99-163. [PubMed: 17237344]

Lahoud H, Prichard RK, McManus WR, Schofield PJ. The dissimilation of leucine, isoleucine and valine to volatile fatty acids by adult Fasciola hepatica. Int. J. Parasitol 1971;1:223-233. [PubMed: 5156166]

Manning RB, Felder DL. Revision of the American Callianassidae (Crustacea: Decapoda: Thalassinidea). Proc. Biol. Soc. Wash 1991;104:764-792.

Menze MA, Clavenna MJ, Hand SC. Depression of cell metabolism and proliferation by membranepermeable and -impermeable modulators: role for AMP-to-ATP ratio. Am. J. Physiol. Regul. Integr. Comp. Physiol 2005a;288:R501-R510. [PubMed: 15458972]

Menze MA, Hutchinson K, Laborde SM, Hand SC. Mitochondrial permeability transition in the crustacean Artemia franciscana: Absence of a $\mathrm{Ca}^{2+}$-regulated pore in the face of profound calcium storage. Am. J. Physiol. Regul. Integr. Comp. Physiol 2005b;288:R501-R510. [PubMed: 15458972]

Nicholls DG, Chalmers S. The integration of mitochondrial calcium transport and storage. J. Bioenerg. Biomembr 2004;36:277-281. [PubMed: 15377857]

Nicholls, DG.; Ferguson, SJ. Bioenergetics 3. Amsterdam: Academic Press; 2002.

Petronilli V, Cola C, Bernardi P. Modulation of the mitochondrial cyclosporin A-sensitive permeability transition pore. II. The minimal requirements for pore induction underscore a key role for transmembrane electrical potential, matrix pH, and matrix Ca2+ J. Biol. Chem 1993a;268:10111016. [PubMed: 7678245]

Petronilli V, Cola C, Massari S, Colonna R, Bernardi P. Physiological effectors modify voltage sensing by the cyclosporin A-sensitive permeability transition pore of mitochondria. J. Biol. Chem 1993b; 268:21939-21945. [PubMed: 8408050]

Pritchard AW, Eddy S. Lactate Formation In Callianassa californiensis and Upogebia pugettensis (Crustacea Thalassinidea). Mar. Biol 1979;50:249-253.

Pruett PS, Azzi A, Clark SA, Yousef MS, Gattis JL, Somasundaram T, Ellington WR, Chapman MS. The putative catalytic bases have, at most, an accessory role in the mechanism of arginine kinase. J. Biol. Chem 2003;278:26952-26957. [PubMed: 12732621]

Rees BB, Hand SC. Regulation of glycolysis in the land snail Oreohelix during estivation and artificial hypercapnia. J. Comp. Physiol. [B] 1991;161:237-246.

Saelens X, Festjens N, Vande Walle L, van Gurp M, van Loo G, Vandenabeele P. Toxic proteins released from mitochondria in cell death. Oncogene 2004;23:2861-2874. [PubMed: 15077149]

Stanzel C, Finelli P. The effects of temperature and salinity on ventilation behavior of two species of ghost shrimp (Thalassinidea) from the northern Gulf of Mexico: a laboratory study. J. Exp. Mar. Biol. Ecol 2004;312:19-41.

Strong SJ, Ellington WR. Expression of horseshoe crab arginine kinase in Escherichia coli and sitedirected mutations of the reactive cysteine peptide. Comp. Biochem. Physiol. B Biochem. Mol. Biol 1996;113:809-816.

Taylor AC, Spicer JL. Metabolic responses of the prawns Palaemon elegans and P. serratus (Crustacea: Decapoda) to acute hypoxia and anoxia. Mar. Biol 1987;95(4):521-530.

Thompson RK, Pritchard AW. Respiratory adaptations of two burrowing crustaceans, Callianassa californiensis and Upogebia pugettensis (Decapoda, Thalassinidea). Biol. Bull 1969;136:274-287.

Tielens AGM. Energy generation in parasitic helminths. Parasitol. Today 1994;10:346-352. [PubMed: 15275412]

Tielens AGM, Rotte R, van Hellemond JJ, Martin W. Mitochondria as we don't know them. Trends in Biochem. Sci 2002;27:564-572. [PubMed: 12417132]

Torres JJ, Gluck DL, Childress JJ. Activity and physiological significance of the pleopods in the respiration of Callianassa californiensis (Dana) (Crustacea: Thalassinidea). Biol. Bull 1977;152:134146. [PubMed: 13871]

Willis, ER. Papers Mar. Lab. Vol. 2. Louisiana State University; 1942. Some mud shrimps of the Louisiana coast. Occas; p. 1-6. 
van Hellemond JJ, Klockiewicz M, Gaasenbeek CPH, Roos MH, Tielens AGM. Rhodoquinone and complex II of the electron transport chain in anaerobically functioning eukaryotes. J. Biol. Chem 1995;270:31065-31070. [PubMed: 8537365]

Zamzami N, Kroemer G. The mitochondrion in apoptosis: how Pandora's box opens. Nat. Rev. Mol. Cell. Biol 2001;2:67-71. [PubMed: 11413468]

Zebe E. Anaerobic metabolism in Upogebia pugettensis and Callianassa californiensis (Crustacea, Thalassinidea). Comp. Biochem. Physiol 1982;72B:613-617. 


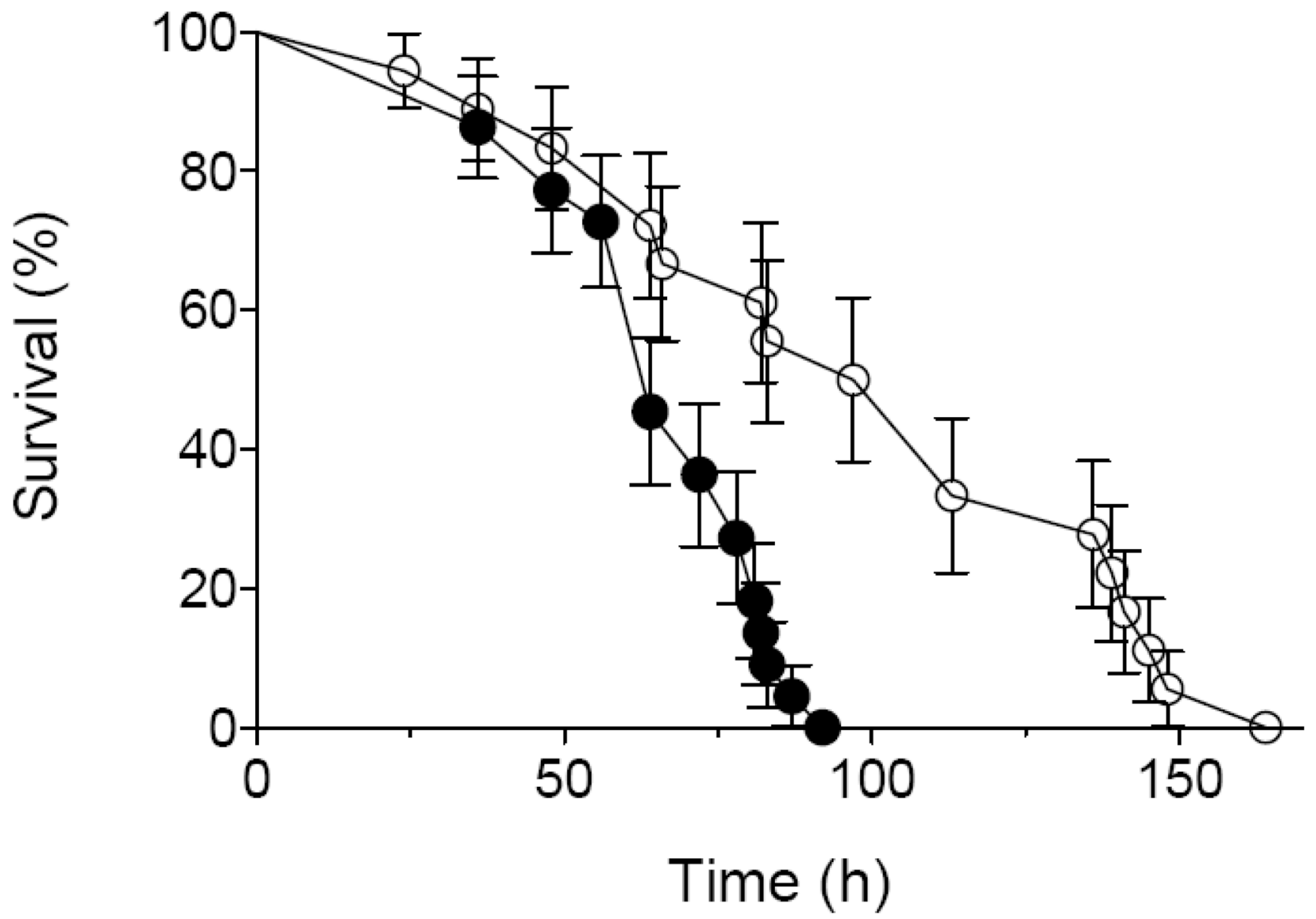

Figure 1.

$\mathrm{LT}_{50}$ (median survival times) of $L$. louisianensis under anoxia for two size classes. The $\mathrm{LT}_{50}$ for large specimens $(>2 \mathrm{~g}, \mathrm{~N}=22$; closed circles) was $64 \mathrm{~h}$ and for small animals $(<1 \mathrm{~g}, \mathrm{~N}=17$; open circles) was $113 \mathrm{~h}$. The non-parametric Kaplan-Meier method was used to calculate $\mathrm{LT}_{50}$ values. A log-rank test (Mantel-Cox) was used to compare the two survival curves, which are statistically different $(\mathrm{P}<0.0001)$. Error bars for the lines $( \pm$ one S.E. $)$ are included simply to indicate the degree of variance within the data sets. 


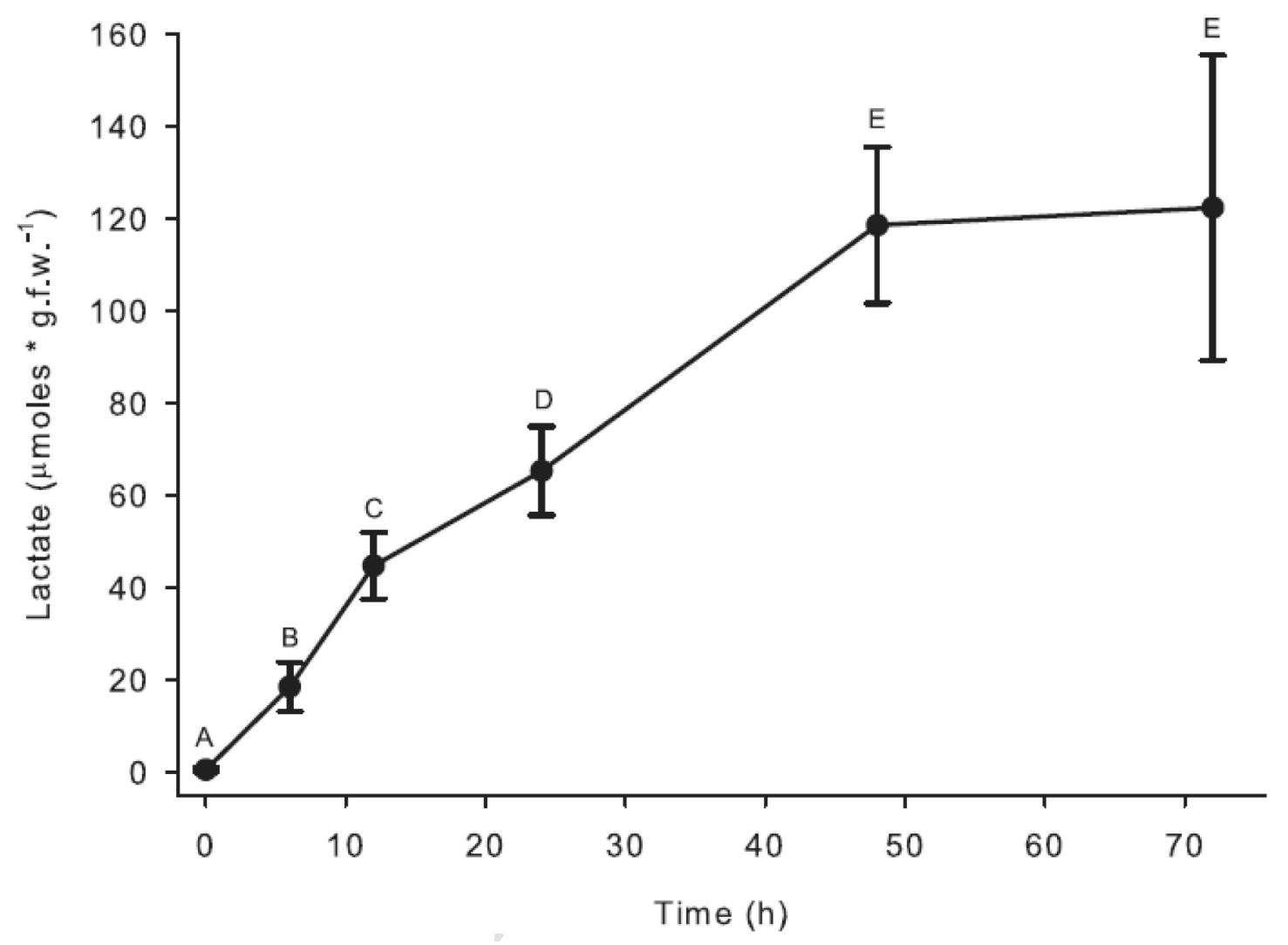

Figure 2.

Lactate accumulation in L. louisianensis during a 72-h time course under anoxia. Lactate increases significantly at each time point until $72 \mathrm{~h}$. Matching letters indicate groups that are not significantly different. Each symbol represents mean \pm SD for $n=6$ experiments. (One-Way ANOVA, Tukey pair-wise comparison, $\mathrm{P}<0.001)$. 


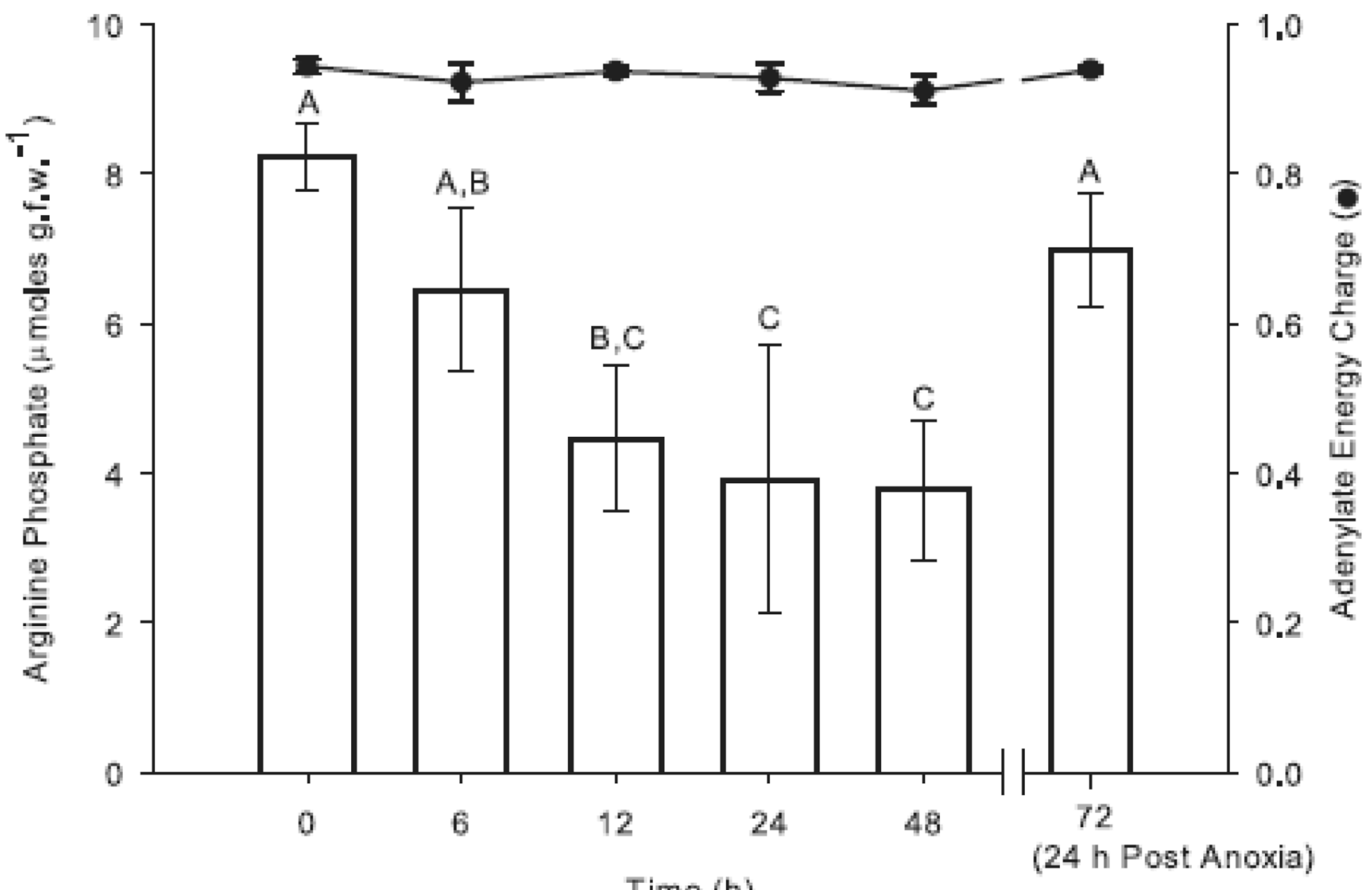

Figure 3.

Arginine phosphate concentration (bars) and adenylate energy charge (•) in adult $L$. louisianensis during a 48-h time course under anoxia and a 24-h recovery period under normoxia. Matching letters indicate groups that are not significantly different. Each bar represents mean $\pm \mathrm{SD}$ ( $\mathrm{N}=4$ for recovery, $\mathrm{N}=5$ for all other groups). One-way ANOVA with Holm-Sidak pair-wise comparison $(\mathrm{P}<0.001)$ was used for statistical comparison. 

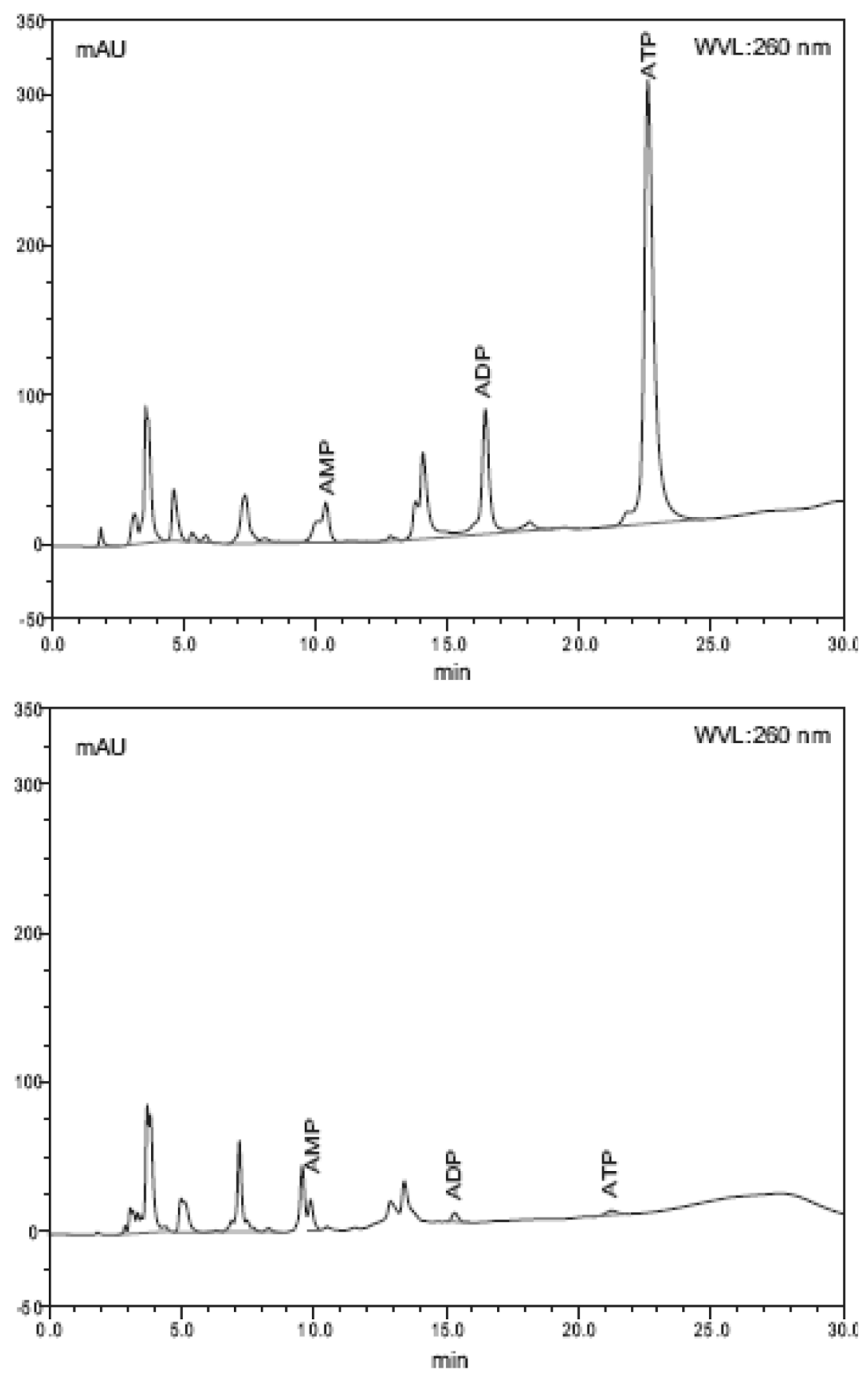

Figure 4.

Analysis of adenylate levels in L. louisianensis. Representative chromatograms from neutralization of a perchloric acid extract from the same animal with $\mathrm{K}_{2} \mathrm{HPO}_{4}$ (upper frame) and $\mathrm{K}_{2} \mathrm{CO}_{3}$ (lower frame). Neutralization with $\mathrm{K}_{2} \mathrm{HPO}_{4}$ fosters substantially higher recovery of ATP. See text for further explanation. 


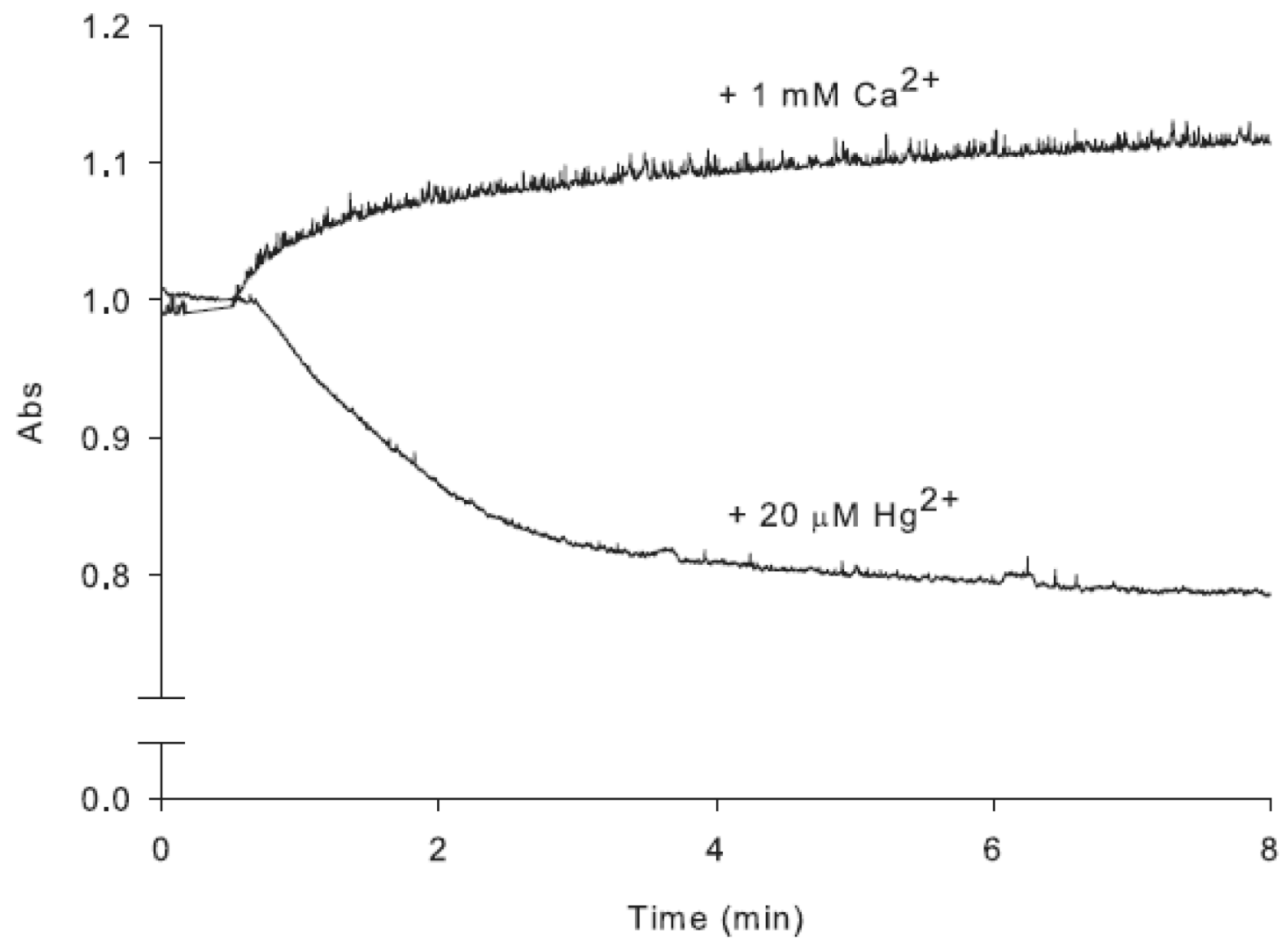

Figure 5.

Effects of $\mathrm{Ca}^{2+}$ and $\mathrm{HgCl}_{2}$ in the presence of $1 \mathrm{mmol}^{-1}$ phosphate on volume changes in isolated mitochondria from hepatopancreas tissues of L. louisianensis. Mitochondrial swelling (i.e., a decrease in absorbance) is not observed after addition of $1 \mathrm{mmol}^{-1} \mathrm{CaCl}_{2}$ to energized mitochondria $\left(0.8 \mathrm{mg}\right.$ protein $\mathrm{ml}^{-1}$ in $300 \mathrm{mmol} \mathrm{l}^{-1}$ sucrose, $150 \mathrm{mmol} \mathrm{l}^{-1} \mathrm{KCl}, 1 \mathrm{mmol} \mathrm{l}{ }^{-1}$ $\mathrm{KH}_{2} \mathrm{PO}_{4}, 5 \mu \mathrm{mol} \mathrm{l}^{-1}$ rotenone, $25 \mu \mathrm{mol} \mathrm{l}^{-1}$ EGTA, and $20 \mathrm{mmol} \mathrm{l}^{-1} \mathrm{~K}$-HEPES, $\mathrm{pH}$ 7.5). Mitochondrial volume increases after addition of $\mathrm{HgCl}_{2}$. 


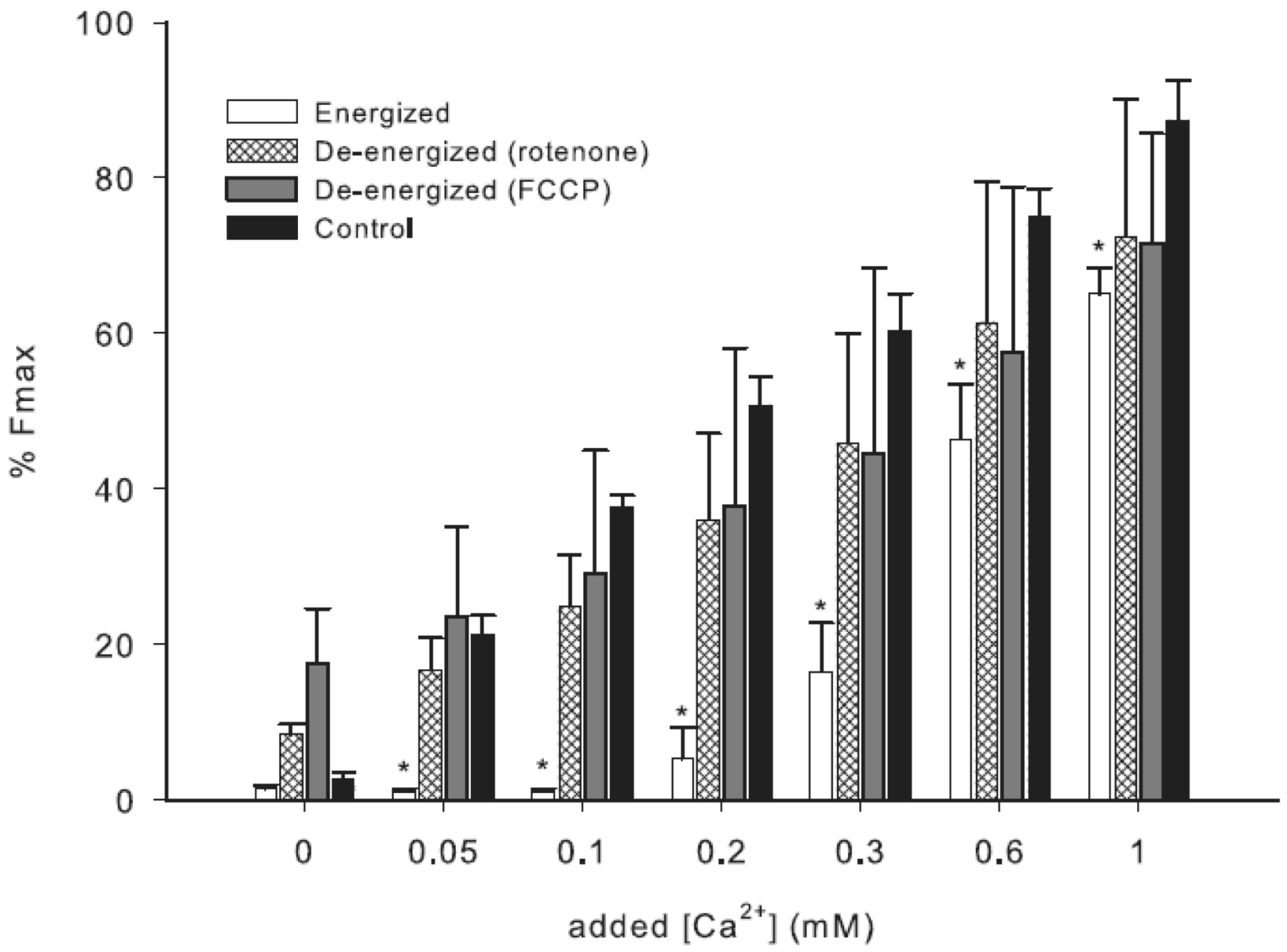

Figure 6.

$\mathrm{Ca}^{2+}$ uptake by isolated mitochondria from hepatopancreas of L. louisianensis. Mitochondria $\left(\sim 0.8 \mathrm{mg}\right.$ protein $\left.\mathrm{ml}^{-1}\right)$ were incubated in exogenously added $\mathrm{Ca}^{2+}$ in the presence of the $\mathrm{Ca}^{2+}$ probe fluo-5N, which measures the extra-mitochondrial $\mathrm{Ca}^{2+}$. Fluorescence was expressed as a percentage of the total fluorescence when the dye is saturated with $\mathrm{Ca}^{2+}(\%$ $\mathrm{F}_{\max }$ ). Control samples contained no mitochondria. Energized mitochondria (succinate plus rotenone) reduced the concentration of exogenously added $\mathrm{Ca}^{2+}$ at all concentrations investigated, relative to controls. De-energized mitochondria (no succinate; with either rotenone or FCCP) were less effective in calcium uptake than energized mitochondria. Each bar represents mean $\pm \mathrm{SD}$ of $\mathrm{N}=4$ experiments. *Significantly different from control (ANOVA, Tukey pairwise comparison, $\mathrm{P}<0.001$ ) 


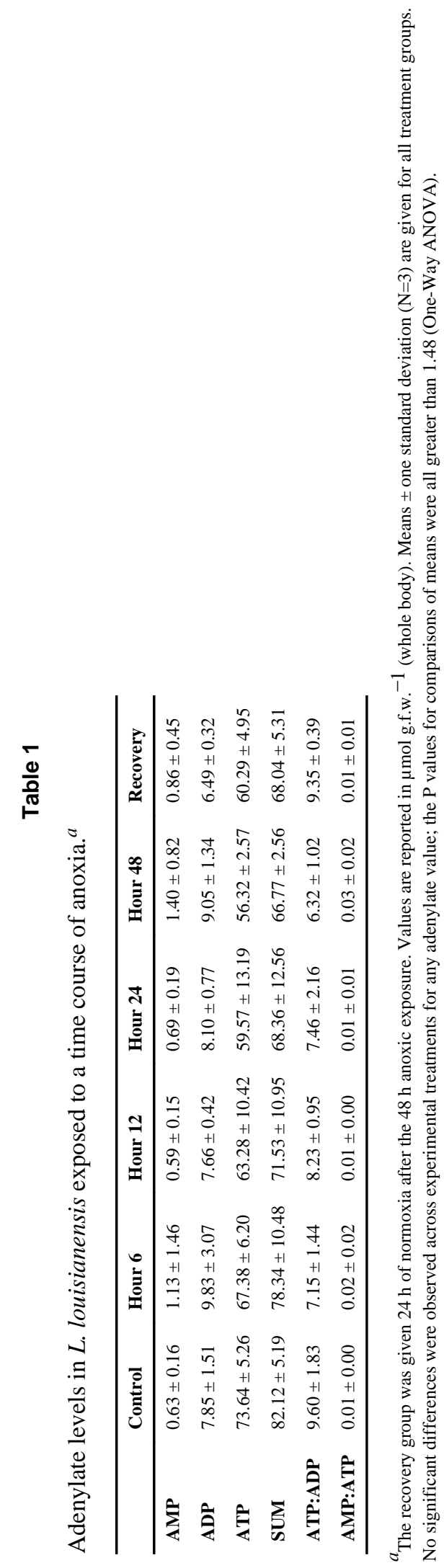




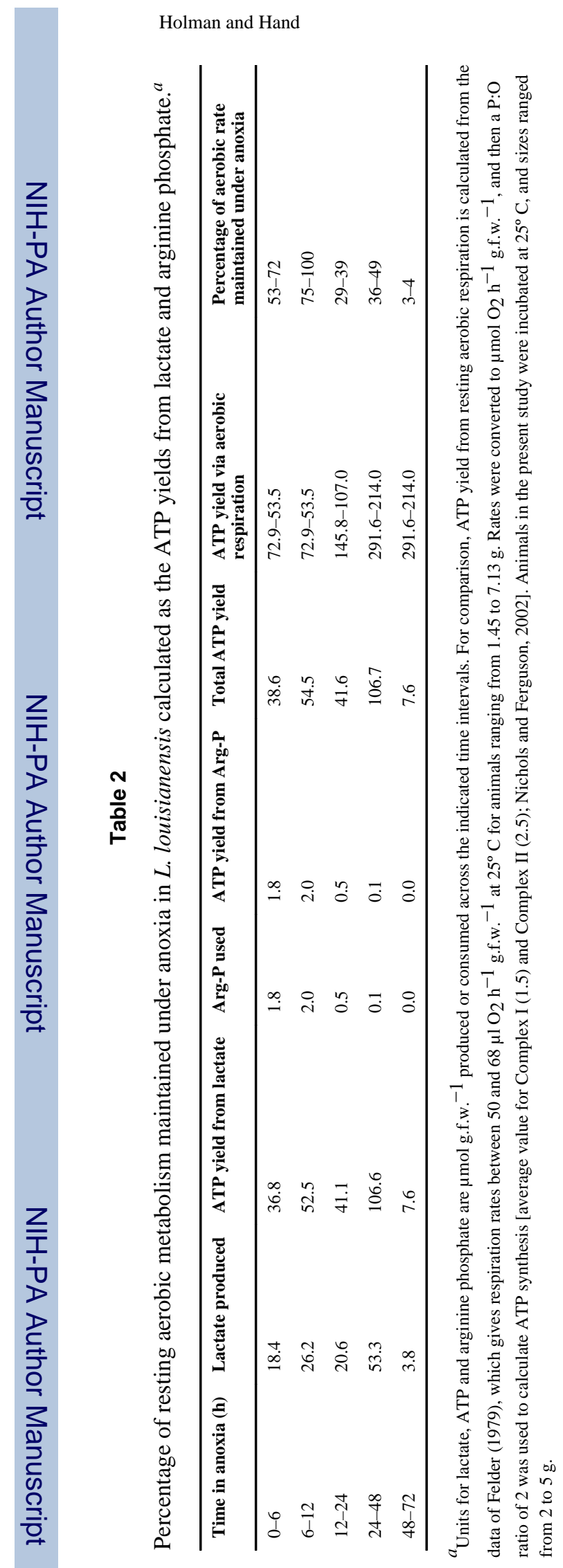

J Exp Mar Bio Ecol. Author manuscript; available in PMC 2010 August 15. 